十二指腸切除の胃酸分泌，血清 gastrin，血清 secretin 飞及济す 影響と,脞液, 胆汁の吻合部潰瘍に対する抑制効果の実験的検討

\author{
奈良県立医科大学第 1 外科（指導：白鳥常男教授）
}

森 本 洋 一

\title{
INFLUENCES OF DUODENECTOMIES ON HEIDENHAIN ACID SECRETION, SERUM GASTRIN, AND SERUM SECRETIN RESPONCE AND \\ INHIBITIVE EFFECTS OF BILE AND PANCREAS JUICE ON ANASTOMOTIC ULCERATION
}

\section{Yoichi MORIMOTO}

First Department of Surgery, Nara Medical University

(Director : Prof. Tsuneo Shiratori)

膵頭十二指腸切除術，脞全摘術後に頻発する吻合部潰瘍の発生因子を解明する目的で，イヌに Heidenhain pouch を作成し十二指腸切除を施行，酸分泌，血清 gastrin 值，血清 secretin 值を切除前 後で測定しその变動を追究した，更に膵液，胆汁による中和作用の潰場発生に対する抑制効果をみる ために十二指腸切除後に脺液，胆汁を胃空腸吻合部近傍の空腸に diversion した群と，回腸末端に diversion した群の 2 群を作成し吻合部空腸の形態学的観察を行った。

酸分泌は両群ともに十二指腸切除後に顕著な増加がみられた．血清 gastrin 値は両群共にほとんと 差はなかったが血清 secretin 値は明らかに両群共に切除後に増加した。吻合部の観察では空腸に diversion した群では 1 頭にだけ, 回腸に diversion した群では全頭に潰瘍がみられ，膵夜，胆汁によ る中和作用の重要性が示唆された。

索引用語：十二指腸切除と胃酸分泌，膵夜, 胆汁による胃酸の中和，吻合部潰瘍， 血清 gastrin と血清 secretin の変動

\section{I. 緒}

十二指腸潰瘍の成因を考学る上において胃膵相関が 注目を集めている。十二指腸潰煌は高酸を示し，この 攻撃因子である酸に対して抑制的に働く secretin secretin に反応して茀蔵から外分泌される重炭酸塩は 防御因子としての役割が大きいと考兄られている。

一方 secretin 分泌細胞はその $80 \%$ 以上が十二指腸 に存在する ${ }^{122)}$ と考学られているので, 臨床面に招いて この十二指腸が切除される膵頭十二指腸切除術および 䐙全摘術を施行した場合当然術後の潰㕫発生が予想さ れる. 実際, 両術式施行後に発生する吻合部潰瘍はか なり重篤な合併症として注目されており $\mathrm{Scott}^{33}$,

$<1985$ 年 3 月13日受理 $>$ 別别請求先: 森本 洋一

T634 檟原市四条町 840 奈良県立医科大学第 1 外科
Grant $^{4)}$, MaConnell ${ }^{5)}$, Warren 56)の報告によれば羘 頭十二指腸切除術施行例に怙いて $5 \sim 22 \%$, 莝全摘術 施行例では $8 \sim 50 \%$ の吻合部潰瘍の発生率が示されて いる.

そこで今回著者は膵頭十二指腸切除術，膵全摘術後 に発生する吻合部潰瘍の原因を究明するために十二指 腸切除した Heidenhain pouch 犬について酸分泌，血 清 gastrin 值, 血清 secretin 值の変化を食慨刺激下て 測定し，十二指腸切除がこれら三者に及ぼす影響を検 討した。

つぎに secretin に反応して外分泌される脇液（重炭 酸塩）と胆汁は吻合部空腸の酸性化を中和する重要な 防御因子であるが，現在一般的に行なわれている Child 法, Whipple 法などの莝頭十二指腸切除術およ び腪全摘術施行後は中和作用が大きく減弱されること 
が問題となってくる，そこでこの荤液，胆汁の潰瘍発 生に対する防御効果を検討するために十二指腸切除を 施行後膵管, 胆道を回腸末端に吻合し胃空腸吻合部に おける中和作用を除去した場合吻合部空腸に起る形態 学的変化, 特に潰瘍発生を観察し中和作用の意義を分 析した。

以上の二つの実験観察から興味ある知見を得たので その成績について報告する。

\section{II. 実験方法}

実験には雑種成犬を用いつぎの様な手順で行った。 1）まず胃酸分泌測定のため Heidenhain pouch を作 成した. 2）絶食時および食慨刺激下での胃酸分泌，血 清 gastrin, 血清 secretin の測定, 3).十二指腸切除, 苹 管, 胆道の再建，4）十二指腸切除犬で絶食時および食 慨刺激下での胃酸分泌, 血清 gastrin, 血清 secretin の 測定, 5) 摘出標本につき胃空腸吻合部の形態学的観察 などを行った。

\section{A. 実験動物}

実験には $15 \mathrm{~kg}$ 前後の雑種成犬を用いた。使用したイ 又は約60頭におよぶが潰瘍による穿孔や手術による腹 膜资などの合併により死亡する例が多く、データを系 統的に集積できた10頭について述べる。

\section{B. 麻醉}

硫酸 atropine $0.03 \mathrm{mg} / \mathrm{kg}$ 它実験直前に投与し， thiopentalsodium $20 \mathrm{mg} / \mathrm{kg}$ で麻酔を導入し, 直ちに 挿管, 実験動物用換気器装置に接続した. 麻酔の維持 には thiopentalsodium $5 \mathrm{mg} / \mathrm{kg}$ の静脈内投与を経時 的に繰り返して行った.

C. Heidenhain pouch の作成と胃液検査

無菌的に開腹し，胃体中部を中心とした大弯側を用 いて Heidenhain pouch を作成した。術後 3 週間を経

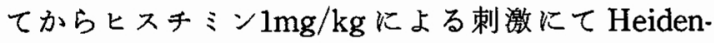
hain pouch から胃液を採取し酸分泌を測定, Heidenhain pouch の有用性を確めた。胃液検查は24時間絶食 の後，早朝空腹時に1時間にわたり Heidenhain pouchより胃液を採取し，これを絶食時酸分泌(BAO) とした。この絶食時酸分泌を摂取した後，ウシ肝 $200 \mathrm{~g}$ に水 $250 \mathrm{ml}$ を加え，煮たものを経口投与乙食慨刺激を 施行，刺激後90分にわたり15分間隔で Heidenhain pouch よりの胃液を採取しこれを刺激分泌（MAO）と した。これら絶食時酸分泌，食餌刺激時酸分泌の検查 を日を变えて $2 \sim 3$ 回絽り返して施行し，これらの平 均値を十二指腸切除前の測定值とした。この胃液検查 の終了後, 後述する様に十二指腸切除を行い, 十二指
腸切除後 3 週間を経てから十二指腸切除前に行ったと 全く同様な胃液検查を行い，これを十二指腸切除後の 測定値とした。胃液検查の測定には Radiometer 社製 の自動滴定装置を用い $0.1 \mathrm{~N}, \mathrm{NaOH}$ にて pH-stat で endpoint $\mathrm{pH} 7.0$ まで滴定し測定した。

D. 血清 gastrin 値と血清 secretin 値の測定

血清 gastrin と血清 secretin の測定は十二指腸切除 術前後に胃液検查に平行して行った。すなわち絶食時 の採血，ついで食餌刺激後は刺激後 90 分にわたり15分 間隔で採血した。採血は外䝺静脈より行い，血清 gastrin, 血清 secretin の測定には Radioimmunoassay を 用い二抗体法にて行った。

\section{E．十二指腸切除々膵管，胆道の再建}

上述した十二指腸切除前の酸分泌，血清 gastrin, 血 清 secretinなどの一連の測定検查が終了後十二指腸 切除を行った。切除範囲は図 $1 \mathbf{a}$ に示すごとく幽門輪 より(幽門輪を含む) $50 \mathrm{~cm}$ とした.これは Treitz band より約 $10 \mathrm{~cm}$ 肛門側まで切除されることになる。この 際荤管を小腸に吻合するため，䐙管の開口部を中心に 直径約 $1 \mathrm{~cm}$ の十二指腸を円形状に残存させた。胃空腸 吻合は图 $1 \mathbf{b}, \mathbf{c}$ のごとく端々吻合にて行った。

つぎに膵管, 胆道の再建として図 $1 \mathrm{~b}$ に示す様に胃 空腸吻合部より $5 \mathrm{~cm}$ 肛門側の空腸に胆虽空腸吻合を 行い，更にその $9 \mathrm{~cm}$ 肛門側に膵管開口部を吻合した。

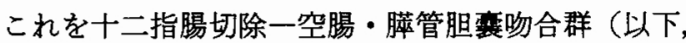
空腸一荤・胆吻合群）とした。

また別に荤液，胆汁の潰汮発生に対する抑制因子と しての影響力を検討するために，図 $1 \mathbf{c}$ に示すごとく 回腸末端より $20 \mathrm{~cm}$ 口側の回腸に胆襄を吻合し，この 回腸胆囊吻合部より $9 \mathrm{~cm}$ 口側の回腸に苹管開口部を 吻合した。これを十二指腸切除一回腸・荤管胆震吻合 群（以下，回腸一桠・胆吻合群）とした。

F. 胃空腸吻合部の形態学的観察

十二指腸切除後の一連の測定検查の終了後（十二指 腸切除後 1 力月目）に屠殺し, 胃, 空腸を摘出, 吻合

\section{図 1 十二指腸切除々再建}

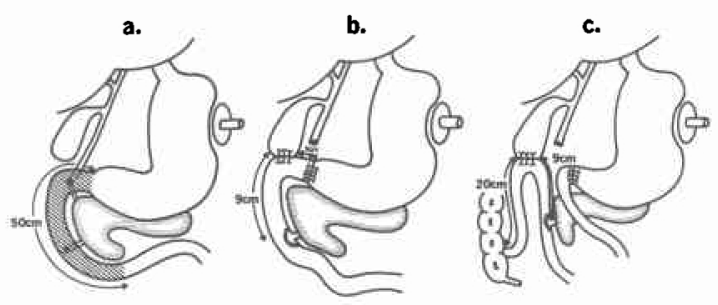

切除籍围

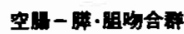


部の胃および空腸粘膜における変化を肉眼的，組織学 的に観察検討した.

\section{III. 実験成績}

A. 十二指腸切除, 空腸一膵 - 胆吻合群

1. 胃酸分泌

十二指腸切除前後における䋓食時から，食餉刺激後 15分間隔で測定した 90 分間の酸分泌の測定値を図 2 に 示した.

これらの測定値のらち絶食時酸分泌（BAO）を十二

図 2 空腸一䐁・胆吻合群の手術前後の食慨刺激時酸 分泌

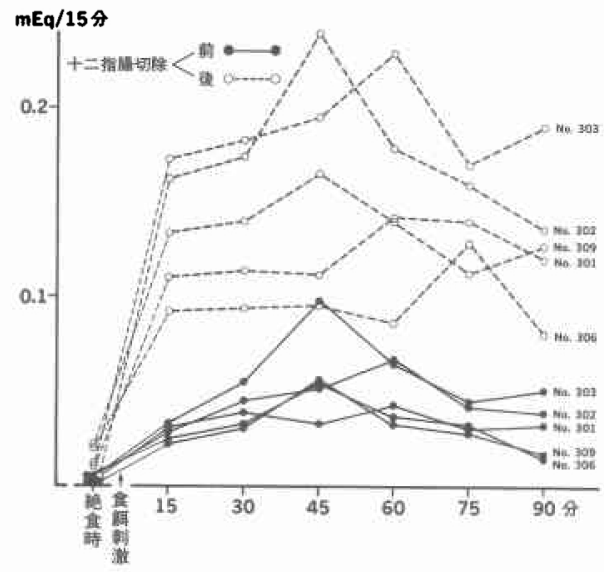

図 3 空腸一荤・胆吻合群の手術前後の酸分泌

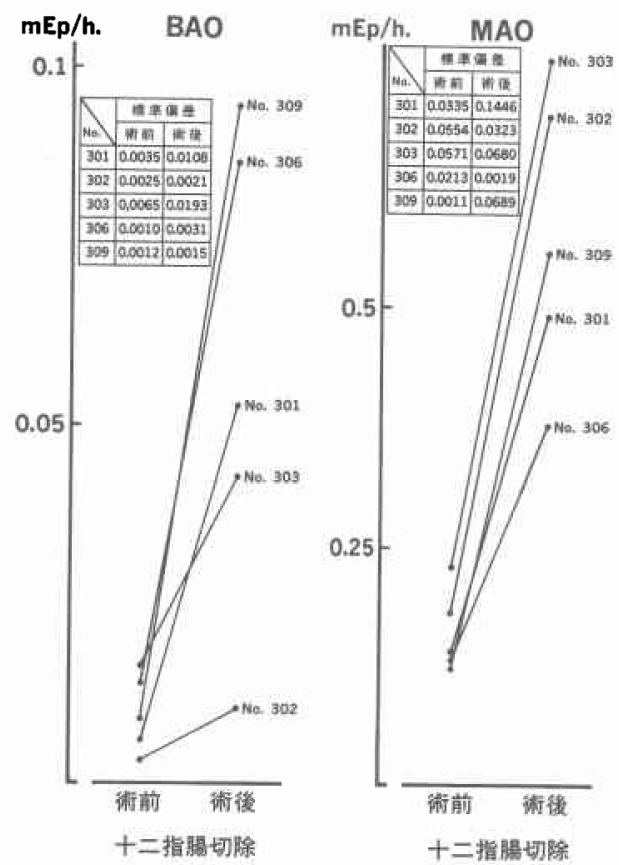

指腸切除前後で比較すると図 3 の BAOに示すごと く, 切除前はNo. 301は0.0067 \pm 0.0035 , No. 302は $0.0037 \pm 0.0025$, No. 303 は $0.0167 \pm 0.0065$, No. 306

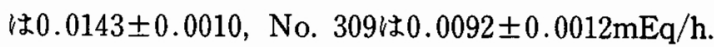

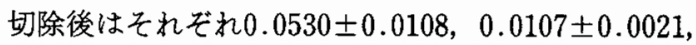
$0.0430 \pm 0.0193,0.0886 \pm 0.0031,0.0945 \pm 0.0015$ $\mathrm{mEq} / \mathrm{h}$. となり十二指腸切除前に比べ切除後にはそれ ぞれ7.9，2.9，2.6，6.1，10.3倍と全頭に増加がみら れた。 また 5 頭の平均值でみても切除前 $0.0101 \pm$ $0.0054 \mathrm{mEq} / \mathrm{h}$. 切除後は $0.0580 \pm 0.0308 \mathrm{mEq} / \mathrm{h}$. とな り切除後は切除前の約 5.7 倍となり明らかな增加傾向 がみられた $(\mathrm{p}<0.05)$.

つぎに食慨刺激後酸分泌（MAO）をみると図 3 の MAOK示す様に十二指腸切除前にはNo. 301は $0.1375 \pm 0.0335$, No. 302 は0.1818 \pm 0.0554 , No. 303

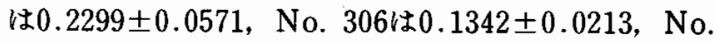
309 は $0.1256 \pm 0.0011 \mathrm{mEq} / \mathrm{h}$.を示し，切除後はそれぞ れ $0.4934 \pm 0.1446,0.7004 \pm 0.0323,0.7604 \pm 0.0680$, $0.3796 \pm 0.0019,0.5605 \pm 0.0689 \mathrm{mEq} / \mathrm{h}$. となり切除 前に比べ切除後はそれぞれ3.6，3.9，3.3，2.8，4.5倍 と切除後明らかな増加が全頭に認められた，5頭の平 均値をみると切除前が0.1618 $00.0493 \mathrm{mEg} / \mathrm{h}$., 切除後 は0.5789 $0.1543 \mathrm{mEq} / \mathrm{h}$. となり切除後は切除前の 3.6 倍と有意な増加を示した $(\mathrm{p}<0.01)$.

以上のことょり十二指腸切除後は絶食時, 食餌刺激 時の何れの場合でも切除前に比べて明らかな酸分泌の 増加がみられた。

2. 血清 gastrin

4 頭にのみ成績を得ることができたのでその成績に ついて述べる。

\section{十二指腸切除前後に扰ける絶食時から食餌刺激後 15}

図 4 空腸一荤・胆吻合群の手術前後の食慨刺激時血 清 gastrin 值

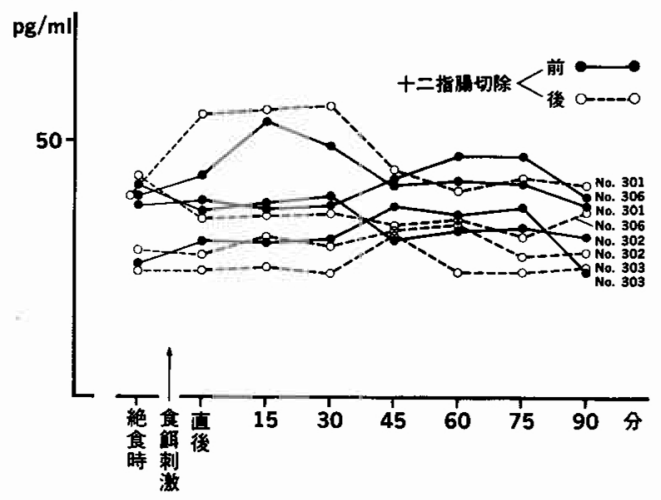


分間隔で測定した 90 分までの測定値を図 4 に示した。 これらの測定値のらち絶食時血清 gastrin 值を十二指 腸切除前後で比較すると図 5 の絶食時にみられる様に 十二指腸切除前は No. $301 か ゙ 40 \pm 0.5$, No. 302は $42 \pm$ 0, No. 303 は $26 \pm 7.0$, No. 306 は $38 \pm 0.5 \mathrm{pg} / \mathrm{ml}$, 切除 後はそれぞれ $40 \pm 11.1,29 \pm 2.0,25 \pm 0,44 \pm 26.9 \mathrm{pg} /$ $\mathrm{ml}$ となり, 切除前に比べて切除後には 1 頭(No. 306) は增加 (16\%), 2 頭 (No. 301, No. 303) は不変 ( $0 \%,-4 \%), 1$ 頭 (No. 302) は诚少 (-31\%) が みられ，4 頭全体の平均値からみると切除前 $36.5 \pm 6.2$ $\mathrm{pg} / \mathrm{ml}$, 切除後は $34.5 \pm 7.8 \mathrm{pg} / \mathrm{ml}$ となり, 切除後にわ ずかな减少となったが統計学的検定では有意差は認め られなかった。

つぎに食餌刺激後 90 分までの 7 回の測定値の 1 頭ご との平均血清 gastrin 值をみると図 5 の食慨刺激時に 示されるごとく，十二指腸切除前はNo. 301が45士 5.2, No. 302 は5 2 2.9, No. 303 は3 34 4, No. 306 は $42 \pm 4.3 \mathrm{pg} / \mathrm{ml}$ で切除後はそれぞれ $49 \pm 7.2,31 \pm$ $2.4,26 \pm 2.7,36 \pm 1.7 \mathrm{pg} / \mathrm{ml}$ となり切除前に比べ切除 後は 1 頭(No. 301) に軽度増加 ( $9 \%$ )， 3 頭(No. 302, No. 303, No. 306) に减少 $(-11 \%,-21 \%,-14 \%)$ がみられた， 4 頭全体の平均值でみると十二指腸切除 前が38.8 $44.9 \mathrm{pg} / \mathrm{ml}$, 切除後は $35.5 \pm 8.6 \mathrm{pg} / \mathrm{ml}$ とな り十二指腸切除後に減少の傾向が認められた $(\mathrm{p}<$ $0.05)$.

以上のことから十二指腸切除前後を比較すると絶食 時には有意差はみられず，食慨刺激時には切除前に比 べ切除後に減少傾向が観察された。

3. 血清 secretin

図 5 空腸一膵・胆吻合群の手術前後の血清 gastrin 値
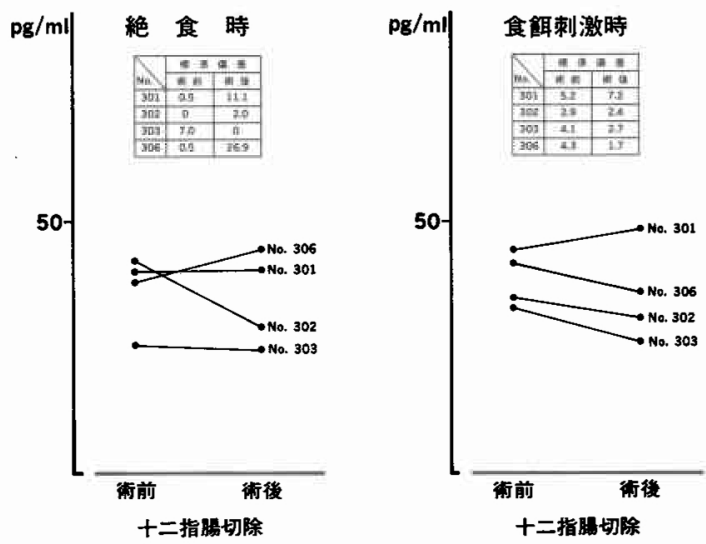

十二指腸切除前後に和ける絶食時から食䬲刺激後 15 分間隔で測定した90分までの測定值を図 6 に示した。 これらの測定値のうち絶食時血清 secretin 値を十二 指腸切除前後で比較すると図 7 の絶食時のごとく十二

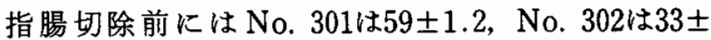
4.8, No. 303は63土4.1, No. 306は36士0.9, No. 309

困 6 空腸一滕・胆吻合群の手術前後の食聑刺激時血 清 secretin 値

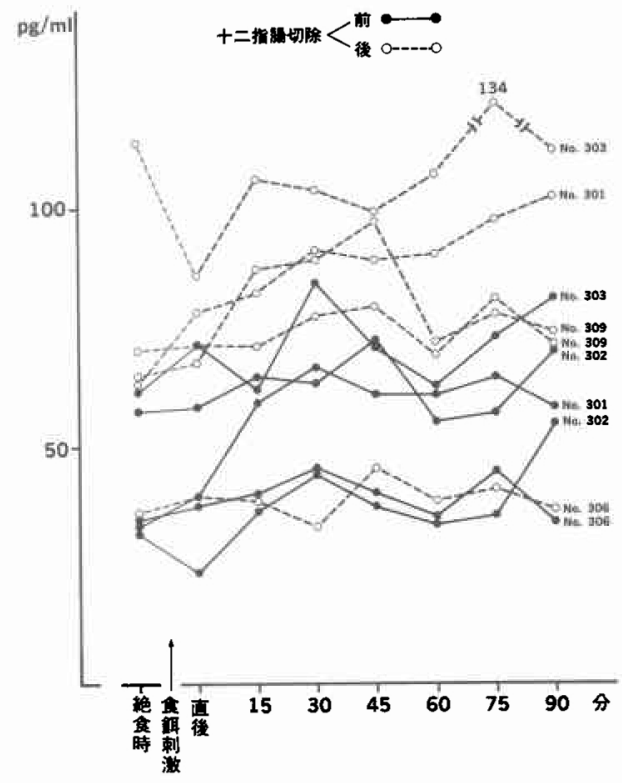

図 7 空腸一膵・胆吻合群の手術前後の血清 secretin 值

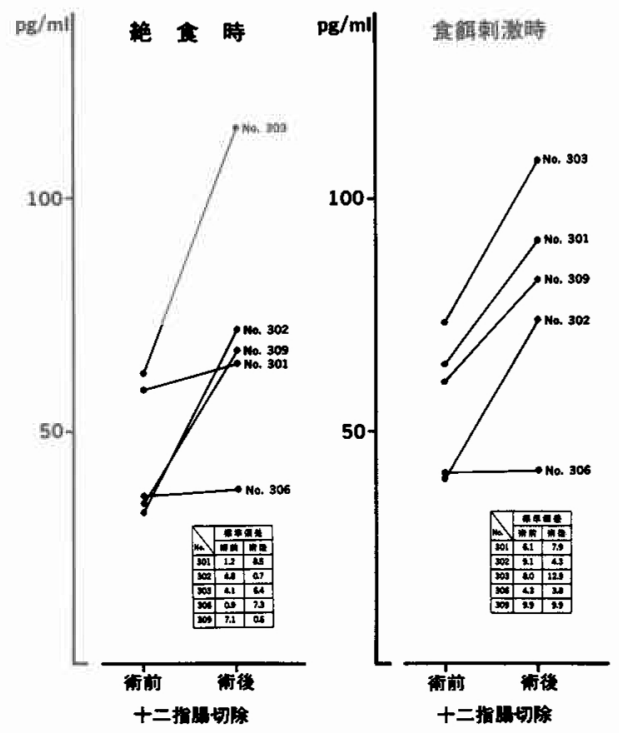


は $35 \pm 7.1 \mathrm{pg} / \mathrm{ml}$, 切除後はそれぞれ $65 \pm 8.5,72 \pm 0.7$ ， $116 \pm 6.4,37 \pm 7.3,68 \pm 0.6 \mathrm{pg} / \mathrm{ml}$ となり十二指腸切 除前に比べて 5 頭中 3 頭 (No. 302, No. 303, No. 309）に明らかな增加 (118\%，84\%，94\%)，一頭 (No. 301）は軽度增加（9\%), 残り 1 頭 (No. 306) はほぼ 不変（3\%）であった， 5 頭全体の平均值でみると十 二指腸切除前は $45 \pm 13 \mathrm{pg} / \mathrm{ml}$, 切除後は $72 \pm 25 \mathrm{pg} / \mathrm{ml}$ となった。しかし検定上からは有意差があるとは言え なかった $(0.05<\mathrm{p}<0.1)$.

食餌刺激後 90 分までの 7 回の測定値の 1 頭ごとの平 均血清 secretin 值でみると図 7 の食䬲刺激時にみら れるごとくで，十二指腸切除前ではNo. 301は65土 6.1, No. 302 は0 40.1 , No. 303 は $74 \pm 8.0$, No. 306 は41士4.3， No. 309 は $83 \pm 9.9 \mathrm{pg} / \mathrm{ml}$, 切除後はそれぞ

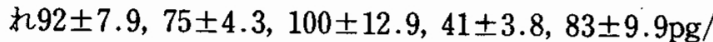
$\mathrm{ml}$ となり十二指腸切除前に比べ切除後には 4 頭（No. 301 , No. 302 , No. 303 , No. 309) に増加 (42\%, $88 \%$, 47\%，36\%)がみられ残り 1 頭(No. 306)は不変であっ た. 5 頭全体の平均値でみると切除前が $56 \pm 13.5 \mathrm{pg} /$ $\mathrm{ml}$, 切除後には $80 \pm 22.5 \mathrm{pg} / \mathrm{ml}$ となり, 切除後には $43 \%$ の増加がみられ有意差があると判断された（ $\mathrm{p}<$ 0.01 ).

以上の成績より血清 secretin 值は十二指腸切除前 に比べ絶食時では有意差は認められなかったが食餉刺 激時には明らかに増加していると考只られた。

B. 十二指腸切除, 回腸一膵・胆吻合群

1. 胃酸分泌

図 8 回腸一荤・胆吻合群の手術前後の食慨刺激時酸 分泌

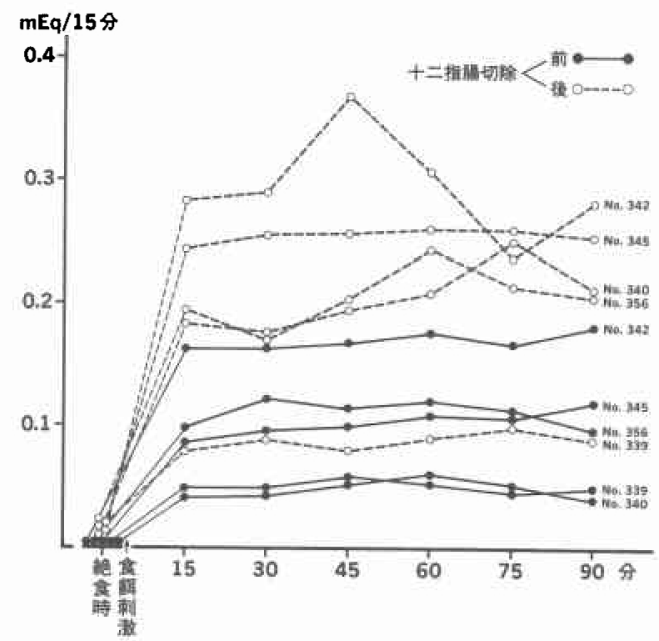

十二指腸切除前後における絶食時から食慨刺激後 15 分間隔で測定した 90 分間の酸分泌の測定値を図 8 に示 した。これらの測定値のらち䋓食時酸分泌 (BAO) を 十二指腸切除前後で比較すると図 9 の BAO に示すご とく, 十二指腸切除前ではNo. 339は0.0001士0, No. 340 は0.0073 \pm 0.0037 , No. 342は0.0043 \pm 0.0039 , No.

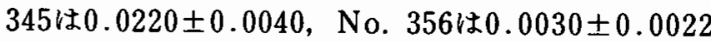
$\mathrm{mEq} / \mathrm{h}$. , 切除後はそれぞれ0.0590士0， $0.0495 \pm$ $0.0395,0.0255 \pm 0.0005,0.0860 \pm 0.0206,0.0450 \pm$ $0.0200 \mathrm{mEq} / \mathrm{h}$. となり十二指腸切除前に比べ切除後に はそれぞれ590，13.4，5.8，3.9，15.0倍と全頭に増加 が認められた。 5 頭の平均值でみても切除前は $0.0066 \pm 0.0088 \mathrm{mEq} / \mathrm{h}$. , 切除後は0.0530 00.0211 $\mathrm{mEq} / \mathrm{h}$. となり 7.2倍の増加がみられ有意差が確かめ られた $(\mathrm{p}<0.01)$.

つぎに食慨刺激後酸分泌（MAO）をみると図 9 の MAOKみられるごとく十二指腸切除前には No. 339

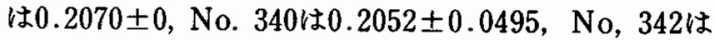
$0.7071 \pm 0.0453$, No. 345 は0.4630 \pm 0.0195 , No. 356 は0.4292士0.0571mEq $/ \mathrm{h}$. , 切除後はそれぞれ0.3610士 $0,0.8421 \pm 0.1385,1.2230 \pm 0.0975,0.8583 \pm 0.140$, $1.0552 \pm 0.565 \mathrm{mEq} / \mathrm{h}$. となり切除前に比べ切除後は それぞれ1.7，4.2，1.7，1.9，2.5倍と全頭に増加が認 められた。 5 頭の平均値をみると十二指腸切除前は $0.4015 \pm 0.2093 \mathrm{mEq} / \mathrm{h}$. , 切除後には0.8676 \pm 0.3235 $\mathrm{mEq} / \mathrm{h}$. となり切除前の2.2倍の増加を示し有意差が 認められた $(\mathrm{p}<0.01)$.

以上のことより十二指腸切除後には絶食時, 食餌刺 激時の何れの場合でも切除前に比べて明らかな酸分泌

図 9 回腸一膵・胆吻合群の手術前後の酸分泌
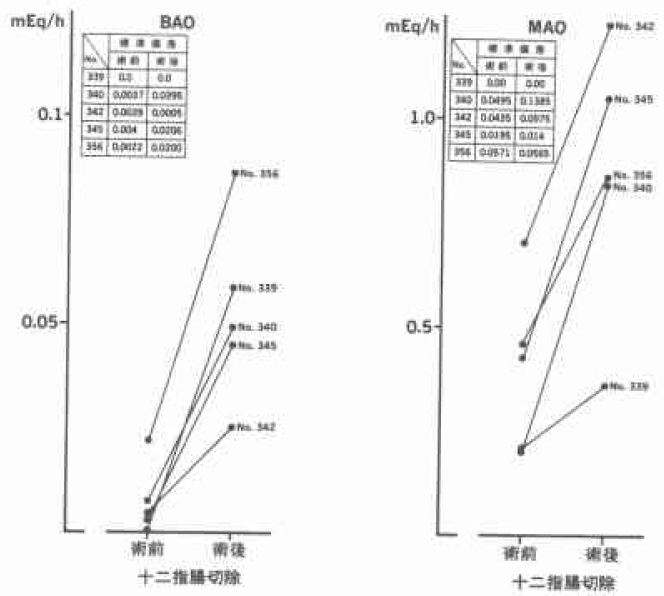
の增加がみられた。 また回腸一朠・胆吻合群の成積を 空腸一荤・胆吻合群の成績と比較すると両群ともに増 加がみられるが，絶食時酸分泌では回腸一㬸・胆吻合 群の方が，食餌刺激時酸分泌では空腸一荤・胆吻合群 の方がより高い増加率を示した。

2. 血清 gastrin

十二指腸切除前後に扔ける絶食時から食餌刺激後 15 分間隔で測定した 90 分までの測定値を図10に示した。 これらの測定値のうち絶食時血清 gastrin 値を十二指

図10 回腸一腪・胆吻合群の手術前後の食䬣刺激時血 清 gastrin 値

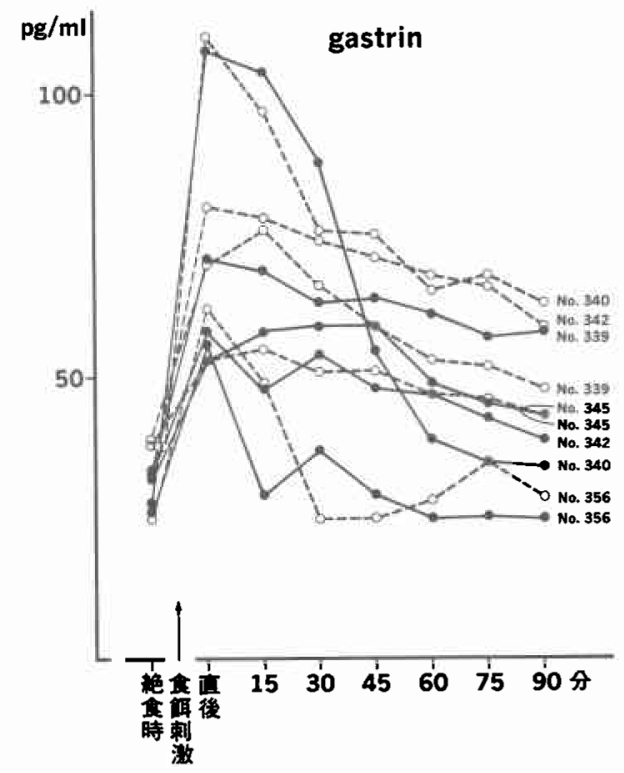

図11 回腸一膵・胆吻合群の手術前後の血清 gastrin 値

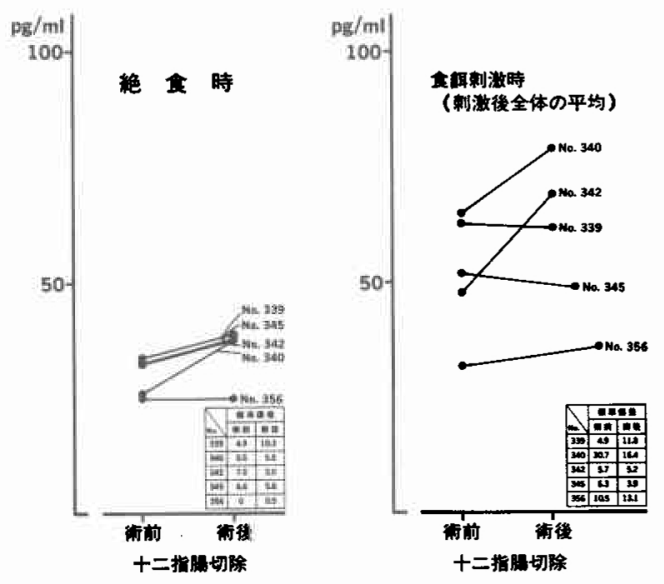

腸切除前後で比較すると図11の絶食時にみられるごと く十二指腸切除前では No. 339は34 4 .9, No. 340は $26 \pm 0.5$, No. 342 は3 $3 \pm 7.0$, No. 345は33土6.6, No.

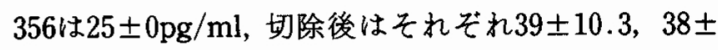
$5.5,38 \pm 2.0,38 \pm 5.8,25 \pm 0.5 \mathrm{pg} / \mathrm{ml}$ となり, 切除前 に比べ切除後は 4 頭 (No. 339, No. 340, No. 342, No. 345)に増加 (15\%，46\%，15\%，15\%)，1頭(No. 356) は不変 $(0 \%)$ であった，5頭の平均値をみると十二 指腸切除前が $30.2 \pm 3.9 \mathrm{pg} / \mathrm{ml}$, 切除後は35.6士5.3pg/ $\mathrm{ml}$ となり, 切除後に増加傾向が認められた $(\mathrm{p}<0.05)$.

食餌刺激後 90 分までの 7 回の測定値の 1 頭ごとの平 均血清 gastrin 值をみると図11の食餌刺激時に示すご とく十二指腸切除前が No. 339は63土4.9, No.340は $65 \pm 30.7$, No. 342 は $48 \pm 5.7$, No. 345 は2 \pm 6.3 , No. 356 は $32 \pm 10.5 \mathrm{pg} / \mathrm{ml}$, 切除後はそれぞれ $62 \pm 11.8$, $79 \pm 16.4,69 \pm 5.2,49 \pm 3.9,36 \pm 13.1 \mathrm{pg} / \mathrm{ml}$ となり 3 頭(No. 340 , No. 342 , No. 356) は増加(22\%, 44\%, $13 \%$ )，1頭 (No. 345) は軽度減少 (-6\%), 残り 1 頭 (No. 339) は注ぼ不変 (-2\%) であった. 5 頭の 平均値をみると十二指腸切除前は $52 \pm 11.9 \mathrm{pg} / \mathrm{ml}$, 切 除後は $59 \pm 15.1 \mathrm{pg} / \mathrm{ml}$ となり有意な差は認められな かった $(\mathrm{p}>0.1)$.

以上の成績より血清 gastrin 値は絶食時には十二指

図12 回腸一䏝・胆吻合群の手術前後の食餌刺激時の 血清 secretin 値

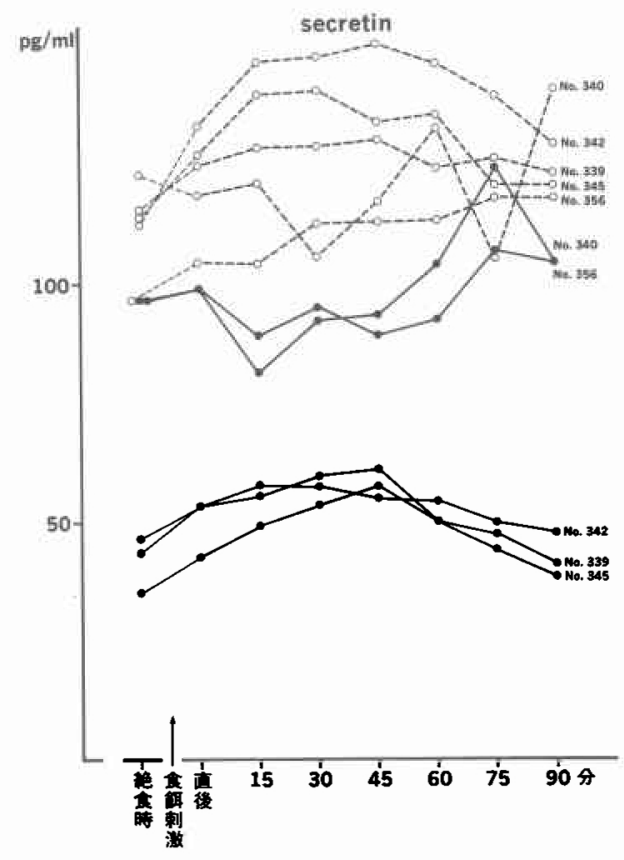


腸切除後に増加傾向を認め, 食餉刺激時では差はみら れなかった。

空腸一莝・胆吻合群と回腸一腪・胆吻合群の成績を 検討すると絶食時では回腸一荤・胆吻合群で増加傾向 が，食慨刺激時では空腸一膵・胆吻合群で減少傾向が みられているが，しかし両群にみられる増加减少傾向 はともに平均で $5 \mathrm{pg} / \mathrm{ml}$ 前後の差であり, 測定精度か ら考觉ると実際的にはほとんど差はないものと思われ る.

3. 血清 secretin

十二指腸切除前後における絶食時から食餌刺激後 15 分間隔で測定した 90 分までの測定値を図12に示した.

これらの測定値のうち絶食時血清 secretin 值を十二 指腸切除前後で比較すると図13の絶食時に示すごと く, 十二指腸切除前にはNo. 339 は $47 \pm 8.1$, No. 340

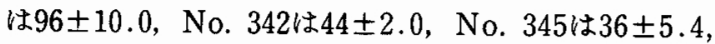
No. 356 は $96 \pm 3.5 \mathrm{pg} / \mathrm{ml}$, 切除後はそれぞれ $114 \pm 4.3$ ， $122 \pm 6.5,111 \pm 11.0,113 \pm 5.3,96 \pm 3.5 \mathrm{pg} / \mathrm{ml}$ となり 4 頭（No. 339 , No. 340 , No. 342 , No. 345) には明 らかな增加 (143\%，27\%，152\%，214\%) がみられ残 り 1 頭 (No. 356) は不変 ( $0 \%$ )であった. 5 頭の平 均では十二指腸切除前が $63.8 \pm 26.5 \mathrm{pg} / \mathrm{ml}$, 切除後は $111.2 \pm 8.5 \mathrm{pg} / \mathrm{ml}$ で切除後は切除前の73\%の增加が みられ有意差が確かめられた $(\mathrm{p}<0.01)$.

食餌刺激後 90 分までの 7 回の測定値の各頭ごとの平 均血清 secretin 值をみると図13の食慨刺激時に示す ごとくで, 十二指腸切除前にはNo. 339は53士6.7, No. 340 は $100 \pm 12.1$, No. 342 は $54 \pm 3.4$, No. 345は $49 \pm 5.9$, No. 356 は $97 \pm 6.4 \mathrm{pg} / \mathrm{ml}$, 切除後はそれぞれ $126 \pm 2.6,120 \pm 12.0,141 \pm 7.8,131 \pm 7.8,110 \pm 5.6$ $\mathrm{pg} / \mathrm{ml}$ となり 5 頭全てに増加（138\%，20\%，161\%, $167 \% ， 13 \%)$ がみられた，5頭の平均值でみても十二 指腸切除前が $71 \pm 22.8 \mathrm{pg} / \mathrm{ml}$, 切除後は126 $\pm 10.4 \mathrm{pg}$ /
四13回腸一䐙・胆伆合群の手術前後の血清 secretin 値

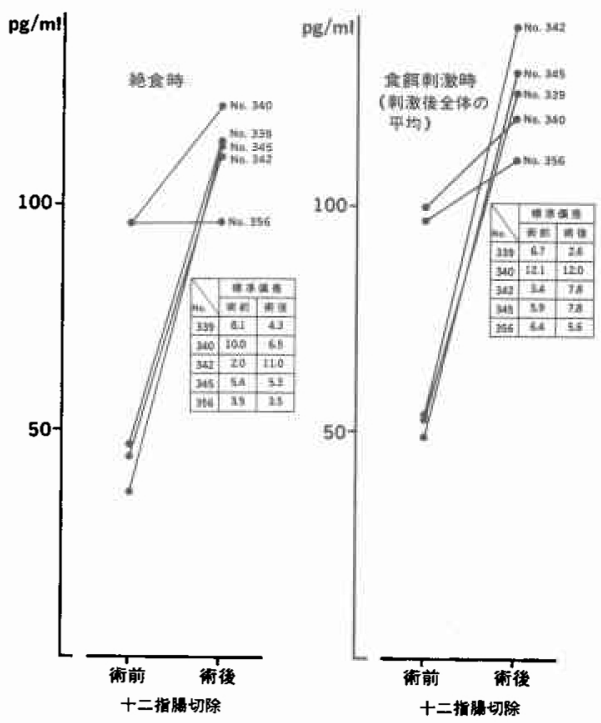

$\mathrm{ml}$ となり切除前に比べ切除後は77\%の増加がみられ 有意差があると判断された（p<0.01）.

以上の成績より血清 secretin 値は絶食時, 食餌刺激 時ともに十二指腸切除後は切除前に比べ増加すること が認められた。この成績を空腸一膵・胆吻合群と比較 すると, 両群共に絶食時および食慨刺激時に血清 secretin 值の増加をみたが空腸一荤・胆吻合群の空腹時 での増加は有意差とは言兄なかった $(0.05<\mathrm{p}<0.1)$.

C. 吻合部空腸粘膜の観察

胃空腸吻合部の形態学的変化，特に吻合部空腸側の 潰瘍発生の有無を観察した。空腸一䐙・胆吻合群では 表 1 のごとく 5 頭中 1 頭にのみ U1 III の線状潰瘍が みとめられ，2頭にはびらんがみられ，残り 2 頭は正 常の粘膜像であった．回腸一茄・胆吻合群では表 1 の ごとく胃空腸吻合部の空腸側に 5 頭全頭において潰痬

表 1 摘出標本の所見

\begin{tabular}{|c|c|c|c|c|c|c|c|}
\hline \multicolumn{4}{|c|}{ 空腸一嵫 - 胆吻合群 } & \multicolumn{4}{|c|}{ 回腸一苹 - 胆吻合群 } \\
\hline No & 潰漡の形態, & 深達度, & 個数 & No & 潰瘍の形態, & 深達度, & 個数 \\
\hline 301 & 線状 & Ul 3 & 3 & 339 & 梋円形 & U1 4 & 3 \\
\hline 302 & & びらん & & 340 & 楕円形 & 穿通 & 4 \\
\hline 303 & 正 & 常 & & 342 & 円形 & 穿通 & 2 \\
\hline 306 & & びらん & & 345 & 円形 & 穿通 & 1 \\
\hline 309 & 正 & 常 & & 356 & 楕円形 & 穿通 & 3 \\
\hline
\end{tabular}

備考 : 深達度は最も大きな潰瘍について示した。 
困 14

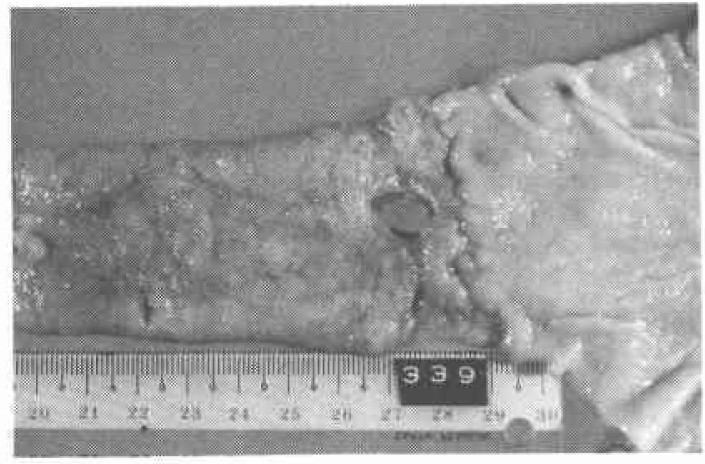

形成が認められ，5頭中 4 頭には図14にみられる様に $2 \mathrm{~cm}$ 以上の大きな穿通性の潰瘍がみられた，他の 1 頭 には楕円形の U1 IV の潰瘍がみられ多発していた。 た潰蕩の周辺は全体として浮腫性でびらんが多発して いるのがいずれの潰瘍例に特いてもみられた。

以上の成績より空腸一腪・胆吻合群では潰瘍発生は 5 頭中 1 頭のみであったが回腸一腪・胆吻合群では 5 頭全頭に潰瘍発生がみられ，これらの潰場は 4 頭が穿 通性の $2 \mathrm{~cm}$ 以上の大きなるのであった.

\section{IV. 考察}

䐙頭十二指腸切除術, 荤全摘術後に発生する吻合部 潰瘍は出現頻度が高く, 多くは消化管出血として認め られる、この吻合部潰怚は再手術を必要としたり, 重 篤な状態にいたることが少なくなく大いに注目を集め ている合併症の一つである。諸家の報告をみると Gilsdorf $ら^{7}$ は荤頭十二指腸切除術を施行した88症例の検 討を行い gastrointestinal bleeding は12例 $14 \%$ にみら れ，この内訳として vagotomyを施行せず50\%以下の 切除範囲の gastrectomy の症例には47例中 9 例 $20 \%$ に, vagotomy か50\%以上の gastrectomy, むしくはそ の両者を施行した症例には41例中 3 例 $7 \%$ に見られ， また gastrointestinal bleeding を来した12症例の死亡 率は75\%であったと報告している。また MaConnell' は膵全摘術を 6 例に行い, 生存例 3 例中 2 例に marginal ulceration がみられたと述べている.この 2 例に はvagotomyは施行されず50\%gastrectomyのみが 行われた，彼は潰瘍が頻発する要因の一つに total pancreatectomy 後の再建術式が ulcerogenic である Mann-Williamson procedure に似ていることをあげ ている。この他にも膵頭十二指腸切除術, 荤全摘術後 に頻発する marginal ulcerに関しては Warrn' Meinke $^{8)}$, Plessis $^{9)}$, Waddel $^{10)}$, Braasch $ら^{11)}$ 多くの人
達によって報告されている。

一方この原因の究明に対しては推論を述べているも のはみられるが実験的に approch した報告は著者が 検索した範囲ではみい出せなかった。

1. 十二指腸切除後の酸分泌, 血清 gastrin 值, 血清 secretin 値

本実験における十二指腸切除後の胃酸分泌をみると 十二指腸切除により空腸一荤・胆吻合群では絶食時酸 分泌が5.7倍, 食餌刺激後の酸分泌が3.6倍々顕著な増 加を示し, 回腸一膵・胆吻合群に执いても絶食時酸分 泌で7.2倍，食䬣刺激時の酸分泌では2.2倍と明らかな 増加がみられた. Brackney ${ }^{12)}$ はイヌについて十二指腸 切除前後の酸分泌を Heidenhain pouchにて測定し， 切除後に酸分泌の亢進するのをみているまた関谷 ら は131ヌを用いて小腸広範切除を行い, その時の酸 分泌と血清 gastrin 值を測定しているが, 顕著な酸分 泌の亢進がみられ血清 gastrin 值にほとんど変動はみ られなかったと報告している，実際に臨床上，小腸広

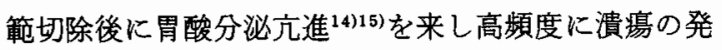
生をみることが報告されている。

以上の報告より考えて十二指腸の切除や小腸の広範 切除により胃酸分泌の妄進を来すことが明らかにされ ていると思われる. しかしこの胃酸分泌の元進ないし 発生機序に関しては不明確な点が多くみられるので若 干の考察を加えてみる。

胃相扣よび腸相に扣ける体液性胃液分泌調節につい ては胃相が胃酸分泌の六進を, 腸相は胃酸分泌の抑制 を行うと考兄られている. 事実, 小腸粘膜からはsecretinをはじめとして GIP，VIPなど胃酸分泌の抑制 を共通の特徵とする一連の消化管ホルモンが分泌され て拉り,これらの消化管ホルモンの障害が二次的に胃 酸分泌の亢進と結びつく可能性が考えられる.した がって十二指腸切除，小腸広範切除により小腸粘膜に おいて産生される各種の胃酸分泌抑制ホルモンの分泌 が除去されるために相対的に胃相が優性となり胃酸分 泌が亢進するものと考えられる。この様に腸相は胃酸 分泌抑制の面から胃液分泌調節に大きな役割を演じて おり，また前述した一連の胃酸分泌抑制ホルモンの大 多数が十二指腸に密集していることを考学ると腸相に おける十二指腸の占める意味は大きいと考えられる.

つぎに本実験に拉ける十二指腸切除後の血清 gastrin 值と血清 secretin 値をみると，血清 gastrin 值は 十二指腸切除前後で絶食時および食䬲刺激時の何れの 場合でも，また空腸一膵・胆吻合群および回腸一膵・ 
胆吻合群の何れにおいても明らかな増減をみなかっ た。したがって胃酸分泌の元進は血清 gastrinによる ものでないことは明らかである。

一方本実験の血清 secretin 值をみると空腸一膵・胆 吻合群は絶食時での増加は有意差があるとは言えな かったが食慨刺激時の増加は明らかで有意差が認めら れた。 また回腸一莝・胆吻合群では絶食時, 食慨刺激 時共に有意な上昇が認められている。

secretin 分泌細胞は十二指腸飞最も多く認められ， 空腸上部にも存在するが空腸下部にいくにしたがって 少なくなると報告12)されている。この報告に立脚する と膵頭十二指腸切除術, 膵全摘術を施行した場合には secretin 分泌細胞が最も多く存在する十二指腸および 空腸上部が除去されることになり血清 secretin 值は 当然减少すると思われる。しかし本実験では血清 secretin 值は逆に上昇するのが観察された。

Hanssen ら ${ }^{16}$ はヒトの朠頭十二指腸切除術, 膵全摘 術後の空腸に acid infusion 乙血清 secretin 值の増加 を来すことから残存空腸にも酸に反応する secretin 分泌細胞が存在すると報告して括り，また Tasse ら は十二指腸を空置した Mann-Williamson procedure においても血清 secretin は術後約2.5倍の増加がみら れたと報告している。この様に十二指腸を切除したり， また十二指腸を空置した場合には血清 secretin值の 増加を来すことが十分に考えられる，本実験において 十二指腸切除後にみられた血清 secretin 値の上昇は 残存した空腸における secretin 分泌細胞がえ進した 胃酸分泌の刺激に反応して secretinを分泌したるの と推察されよう。

つぎに問題となることは明らかな血清 secretin 値 の上昇が認められるにもかかわらず酸分泌は顕著な増 加を示すことである。これに対しては secretin の直接 壁細胞に働いて酸分泌を抑制する能力は gastrin 刺激 下での酸分泌六進に対しては相当な抑制効果を示 す18 20)が， gastrin 刺激以外の酸分泌六進に対しては 抑制効果は小さいといら井原ら ${ }^{21}$ の報告がみられる. したがって本実験に打ける胃酸分泌の元進は secretin により余り抑制されず，また gastrin に関係しない性 質のものと思われる。

以上, 本実験から十二指腸切除後には胃酸分泌がえ 進し, 血清 gastrin 值には増減をみないが，血清 secretin 値は増加することが明らかなとなり, 吻合部潰 場の発生には胃酸分泌の六進が大きな原因的役割を演 じていると考えられた。
2. 吻合部潰場の発生からみた空腸一恠・胆吻合群と 回腸一膵・胆吻合群の比較

摘出標本について吻合部潰瘍を観察すると空腸 一膵・胆吻合群では 5 頭中 1 頭だけに吻合部空腸に潰 瘍がみられ，2頭にはびらんが, 残り 2 頭は正常範团 であった。これに対し回腸一朠・胆吻合群では 5 頭全 頭に潰場の発生がみられ，潰瘍自体もほとんどが2 $\mathrm{cm}$ 以上の大きな潰愓で 4 頭に穿通しているのがみられ た. すなわち吻合部潰湟は明らかに空腸一荤・胆吻合 群よりも回腸一膵・胆吻合群に多発した。

この吻合部潰瘍発生の相違についてまず酸分泌を検 討すると, 両群共に顕著な増加がみられているが, 絶 食時酸分泌では回腸一荤・胆吻合群により高い増加率 が，また食慨刺激時酸分泌では空腸一膵・胆吻合群の 方がより高い増加を示した。 その理由としては回腸 一膵・胆吻合群の場合, 消化酵素が下部消化管（回腸 末端）に回避されているので消化吸収が正常に行われ ず，結果として著明な体重減少がみられる様になる。 このことが強いストレスとなり, 絶食時酸分泌におい て空腸一脺・胆吻合群よりやや酸分泌の元進する結果 をるたらしていると推察される。一方, 食慨刺激によ り分泌された胃酸が空腸一膵・胆吻合群では，胃空腸 吻合部を通過し空腸内に到達すると, 空腸に存在した secretin 分泌細胞より secretinが分泌され，その結果 重炭酸塩が分泌され，この重炭酸塩により空腸に達し た胃酸が中和される。しかしながら回腸一膆・胆吻合 群の場合, 重炭酸塩により中和されることがないので 食慨刺激後は上部空腸が常に胃酸に接している状態が 続くことになる．この胃酸の刺激により secretinの分 泌穴進を招来し，この結果若干ではあるが酸分泌の亢 進を抑制したものと解釈できる。これらのことから食 餌刺激後の酸分泌では空腸一腪・胆吻合群の方がより 高い増加率を示したと考えられる。

この様に両群間に酸分泌充進の程度の差は見られた が, 胃酸分泌充進という点では両群とも類似して括り, 胃酸分泌の亢進が吻合部潰瘍の発生の原因になるとい う意味では両群間に大さな違いはないるのと思われ る.

血清 gastrin 値は胃切除術が行われず，幽門前庭部 が温存されたにも拘わらず両群において明らかに増減 はみられず，また両群間にほとんど相違がみられな かった。これに対し血清 secretin 值では回腸一膵・胆 吻合群の方が空腸一膵・胆吻合群に比べ絶食時ではよ り大きい増加の傾向 $(\mathrm{p}<0.05)$ を, 食䬲刺激時では明 
らかにより大きい増加 $(\mathrm{p}<0.01)$ が認められた。この 両群に招ける違いを考察してみると，血清 secretinは 胃酸が空腸内に到達し， secretin 分泌細胞により血中 に放出されることに起因するが，この secretinにより target organである膵より重炭酸塩が外分泌される。 回腸一脞・胆吻合群ではこの重炭酸塩が回腸未端に回 避されているため, 空腸に到達してきた胃酸を中和す ることができずに常に酸に刺激されている状態にな る。このため, secretin 分泌細胞より secretin が常に 分泌され，その結果として空腸一腪・胆吻合群より secretinが有意に上昇したと考学られる. しかし，この血 清 secretin 值の上昇は前述した様に胃酸分泌の強い 抑制にまで及ばなかったことから血清 secretin 值の 上昇は吻合部潰瘍の発生に対し影響は少ないものと考 えられる。

以上，吻合部潰煌の発生因子といら観点から胃酸の 分泌, 血清 gastrin 值, 血清 secretin 値について両群間 の違いを追究したが本質的な違いを見出すことが出来 なかった。このことから本質的な相違としては回腸 一腪・胆吻合群では空腸に到達した胃酸が㬸液, 胆汁 により中和されない状態が長く続くが，空腸一莝・胆 吻合群では中和が適確に行われるといら事があげられ る，この事に関しては Banks $^{22)}$ ，阿部ら ${ }^{23)}$ は脇外分泌 液である重炭酸塩は胃酸を十分に中和しえる能力を保 持していることを指摘している，また元来，消化管は 肛門側に近くなるにしたがって酸に対する防御機能が 弱くなるので茀頭十二指腸切除術, 膵全摘術における 再建術式では胃と吻合する空腸はできるだけ口側より の空腸を利用することが吻合部潰崵の発生防止につな がると言えるであろう。

以上のことから，腪液，胆汁による腸管内の酸の中 和は吻合部潰瘍の発生防止上重要な意義をもつものと 思われる。

Grant ${ }^{4)}$ は Wipple procedure において推論でばある が潰瘍の多発する理由として，(1)荤，胆管と吻合する intestinal loop が長いため满液, 胆汁による胃酸分泌 の中和が効率的に行われていないこと，(2)不十分な範 团の胃切除，(3)满管の術後の狭窄に上る莝液の不足で 酸に対する中和が十分にできないこと，(4)消化管ホル モンである Gastric Inhibitory Polypeptide が酸分泌 を抑制すると考えられているが，この術式のためにそ の balance が崩れ潰瘍の発生しやすい状態になる, (5) ホルモンや粘膜, その他のまだ未知の分野による影響, の 5 つを示している.
臨床上，腪頭十二指腸切除術，膵全摘術が施行され る場合には必ず胃切除術や迷切術が付加されており， この場合 Waddel ら ${ }^{10)}$ の報告にみられる様に酸分泌は 術前に比較して明らかに減少している．これに対し著 者の実験では十二指腸切除を行い whole stomach 温存, 迷切術も付加していないので酸分泌は著しい方 進がみられている。したがって臨床でみられる吻合部 潰瘍之本実験の吻合部潰場の発生を全く同じものとみ ることはできないであろう，が臨床例に打いて子術後 の刺激酸分泌の比較的高い症例に marginal ulcer が みられることが報告されており，吻合部潰瘍の発生に 酸分泌が関与していることは十分に考兄られる。

๖ら一つの理由として膵液, 胆汁による酸分袐の中 和の問題があげられる. 本実験の成績では空腸一膵・ 胆吻合群は 1 頭だけに潰場発生がみられたが，これに 対して回腸一脺・胆吻合群では 5 頭全頭に潰場発生が みられている、食餌刺激時酸分泌ではむしろ空腸 一脺・胆吻合群の方がより大きな増加率を示している ことより考えて，この中和作用のもつ意義は非常に大 きいといえるであろう．したがって萭頭十二指腸切除 術や苹全摘術後の再建術式と乙て橧液, 胆汁の流入が 胃空腸吻合部より離れる Roux-Y 吻合などを採用す ることは吻合部潰瘍の発生上不利な条件となることが 推察される.

現在荤頭十二指腸切除術に対してWhipple 法, Child 法, Cattel 法の $3 つ の$ 術式やその変法が実際に 施行されて㧍り，羘全摘術後の再建もそれと類似した 術式が行われているが，最近では稀液，胆汁が胃空腸 吻合部に分泌され胃酸を中和する様に Billroth I 法の 形式で総胆管と朠を吻合する術式も試みられており， 今後こういった術式が発展することが切望されよう。

\section{V. 結 語}

脞頭十二指腸切除術, 辇全摘術後に吻合部に発生す る潰瘍の原因を解明する目的でイヌに Heidenhain pouch を作成し, 十二指腸切除を施行, 酸分泌, 血清 gastrin 值, 血清 secretin 值を術前後で測定し, その変 動を追究した。

更に洋液，胆汁による中和作用の潰場発生に対する 抑制効果を検討するために十二指腸切除後, 空腸 一膵・胆吻合群之回腸一膵・胆吻合群を作成, 比較検 討を行い以下に示す様な興味ある所見を得た。

1. 胃酸分泌は十二指腸切除により空腸一茀・胆吻合 群では絶食時が5.7倍, 食慨刺敫時で3.6倍, また回腸 一莝・胆吻合群では絶食時7.2倍, 食餪刺激時で2.2倍 
と共に顕著な増加が認められた。

2. 血清 gastrin 值は空腸一膵・胆吻合群では食慨刺 激時で減少傾向が，回腸一莝・胆吻合群では絶食時に 増加傾向がみられたが, 共に平均で $5 \mathrm{pg} / \mathrm{ml}$ 前後のわ ずかな差で測定精度から考光て実際的な意味はないと 思われた。

3. 血清 secretin 値は空腸一膵・胆吻合群では絶食 時の増加は有意差とは言えなかったが食䬲刺激時には 有意な増加をみた。また回腸一膵・胆吻合群では絶食 時, 食餉刺激時共に有意な増加が認められた。両群を 比較すると回腸一膵・胆吻合群の方が増加が大であっ た。

4. 空腸一茄・胆吻合群では潰瘍が 1 頭にみられただ けであったが回腸一膵・胆吻合群では 5 頭全頭に潰瘍 が認められた。

以上のことより吻合部潰瘍発生には高酸と膵液, 胆 汁による中和が関係していることが明らかになった。 したがって苏頭十二指腸切除術，朠全摘術を行う場合 には吻合部に発生する潰煌を防止するための再建術式 として, 酸分泌を抑制する胃切除術か迷切あるいは併 用などを選択し，更に膵液，胆汁による中和が適確に 行われる BI 法を選ぶことなどの配慮が望ましいと考 えられた。

稿を終党るにあたり，ご指導ならびにご校閲を賜った白 鳥常男教授に深甚なる謝意を捧げるととるに，研究にご協 カいただいた教室各位に深く感謝の意を表します。

$$
\text { 文献 }
$$

1) Friedman MHF, Thomas JE: The assay and distribution of secretin. J Lab Clin Med 35 : $366-372,1950$

2) Polak JM, Bloom S, Coulling I et al : Immunofluorescent localization of secretin in the canine duodenum. Gut $12: 605-610,1971$

3) Scott HW Jr, Richard HD, Telfair P et al : The role of vagotomy in pancreaticoduodenectomy. Ann Surg 191 : 688-696, 1980

4) Grant CS, Heerden JA: Anastomotic ulceration following subtotal and total pancreatectomy. Ann Surg $190: 1-5,1979$

5) McConnell DB, Sasaki TM, Garnjobst $W$ et al : Experience with total pancreatectomy. Am J Surg 139:646-649, 1980

6) Warren KW, Poulantzas JK, Kune GA et al : Life after total pancreatectomy for chronic pancreatitis. Ann Surg 164:830-834, 1966

7) Meinke WB, Twomey PL, Guernsey JM et al : Gastrointestinal bleeding after operation for pancreatic cancer. Am J Surg $146: 57-60,1983$
8) Gilsdorf RB, Spanos DP: Factors influencing morbidity and mortality in pancreaticoduodenectomy. Ann Surg 177: 332-337, 1977

9) du plessis DJ, Mieny CJ : Stomal ulceration complicating the "triple anastomosis: Operation for carcinoma of the head of the pancreas. S Afr J Surg 10: 125-127, 1972

10) Waddell WR, Loughry RW : Gastric acid secretion after pancreaticoduodenectomy. Arch Surg $96: 574-585,1968$

11) Braasch JW, Vito L, Nugent FW : Total pan. createctomy for end-stage chronic pancreatitis. Ann Surg 188 : 317-322, 1978

12) Brackney EL, Thal AP, Wangensteen $\mathrm{OH}$ : Role of duodenum in the control of gastric secretion. Proc Soc Exp Biol Med 88:302 $-306,1955$

13）関谷勝行, 中川昭一, 嶋田安秀ほか：小腸広範切除 後の胃酸過分泌汇関する実験的研究. 手術 28 : 517-522，1974

14) Osborne MP, Frederick PL, Sizer TS et al: Mechanism of gastric hypersecretion following Massive intestinal resection clinical and experimental observations. Ann Surg $164: 622-634$, 1966

15) Straus E, Gerson CD, Yalow RS: Hypersecretion of gastrin associated with the short bowel syndrome. Gastroenterology $66: 175-180,1974$

16) Hanssen LE, Karesen R, Aune S: Immunoreactive secretin release in patients after duodenectomy and partial or total pancreatectomy. Scand J Gastroenterol 14 : 997-1000, 1979

17) Tasse DP, Kolts BE, Barefoot SW et al: Serum gastrin and secretin levels after the exalto-Mann-Williamson procedure. Gastroenterology $68: 950,1975$

18) Berstad A, Petersen H: Dose-response relationship of the effect of secretin on acid and pepsin secretion in man. Scand J Gastroenterol $5: 647-654,1970$

19) Johuson LR, Grossman MI : Characteristics of inhibition of gastric secretion by secretin. Am J Physiol 217 : 1401-1404, 1969

20) Nasca $S$, Mignon $M$, Gramatica $L$ et al: Secretin effect on gastrin, gastric secretion in dogs with chronic antral stimulation. Am J Physiol $228: 1775-1781,1975$

21）井原悠紀夫, 朝隈貞雄, 谷 昌尚ほか：十二抗腸内 酸性化による胃分泌抑制機構について一春損犬に 批ける実験的検討一. 胃分泌研会誌 $12: 87-90$, 1980

22) Banks PA, Dyek WP, Dreiling DA et al: Secretory capacity of stomach and pancreas in man. Gastroenterology $53: 575-578, \quad 1967$

23）阿部道夫：胃辇相関の臨床. 医のあゆみ 105 ： 917-928. 1978 